\title{
Status Kerentanan Nyamuk Anopheles spp. terhadap Lambdacyhalothrin 0.05\% di Kecamatan Pituruh, Kabupaten Purworejo
}

\author{
Angelia Galuh Ningtyas ${ }^{1}$, M. Arie Wuryanto ${ }^{1}$, Lintang Dian Saraswati ${ }^{1}$, Praba Ginandjar ${ }^{1}$ \\ ${ }^{1}$ Bagian Epidemiologi dan Penyakit Tropik, Fakultas Kesehatan Masyarakat Universitas Diponegoro \\ *Corresponding author : nv.is.novia@gmail.com
}

Info Artikel : Diterima 05 April 2019 ; Disetujui 04 Januari 2020 ; Publikasi 01 Februari 2020

\begin{abstract}
ABSTRAK
Latar belakang: Nyamuk Anopheles spp merupakan vector penyakit Malaria di Kabupaten Purworejo. Selama ini belum dilakukan monitoring status kerentanan nyamuk Anopheles spp di Kabupaten Purworejo. Tujuan penelitian ini adalah untuk mengukur status kerentanan nyamuk Anopheles spp di Kecamatan Pituruh, Kabupaten Purworejo.

Metode: Penelitian ini mengginakan metode Quasi-experiment dengan sample yaitu nyamuk Anopheles spp hasil koloni F1. Pengujian status kerentanan nyamuk dilakukan pada nyamuk betina sejumlah 120 ekor nyamuk Anopheles spp. Pengujian dilakukan pengulangan sebanyak 6 kali, dengan menggunakan 4 tabung uji kerentanan dan 2 tabung control, masing-masing tabung berisi 20 ekor nyamuk.

Hasil: Hasil penelitian menunjukkan bahwa rata-rata knock down nyamuk Anopheles spp selama 60 menit paparan adalah 19 per repetisi (92,5\%). Setelah holding 24 jam, rata-rata kematian nyamuk Anopheles spp adalah 20 per pengulangan (100\%). Kematian nyamuk mencapai 80 nyamuk (100\%) pada 12 jam. Pada kelompok kontrol, jumlah kematian nyamuk setelah 24 jam adalah 2 ekor $(0,5 \%)$.

Simpulan: Nyamuk Anopheles spp masih rentan terhadap lambdacyhalothrin, sehingga lambdacyhalothrin masih dapat digunakan sebagai kontrol vektor di Kabupaten Purworejo
\end{abstract}

Kata kunci: Anopheles spp, lambdacyhalothrin. Status Kerentanan.

\section{ABSTRACT}

Title: Susceptibility Status of Anopheles spp. to Lambdacyhalothrin 0.05\% in Pituruh Subdistrict, Purworejo District.

Background: Anopheles spp is a malaria mosquito vector in Purworejo Regency. The monitoring of the susceptibility status of Anopheles spp to insecticides not implemented. The purpose of this study was to determine the susceptibility status of Anopheles spp mosquitoes in Pituruh Subdistrict.

Method: The design of this study used quasi-experiment with samples of Anopheles spp mosquitoes as a result of F1 colonization The mosquitoes used for testing are female Anopheles spp mosquitoes. The total number of mosquitoes tested was 120 mosquitoes. Repetition was carried out 6 times with the details of 4 tubes as a treatment and 2 tubes as controls for each tube containing 20 mosquitoes.

Result: The results showed that the average knock down of Anopheles spp mosquitoes during the 60-minute exposure was 19 per repetition (92.5\%). After a 24-hour holding, the average mortality of Anopheles spp mosquitoes was 20 per repetition (100\%). Mosquito deaths reached 80 mosquitoes (100\%) at 12 hours. In the control group, the number of mosquito deaths after 24 hours holding was 2 tails $(0.5 \%)$, so there was no need to make corrections using the Abbots formula

Conclusion: Anopheles spp mosquitoes are said to be susceptible to lambdacyhalothrin so lambdacyhalothrin can still be used as vector control in Purworejo Regency

Keywords: Anopheles spp, lambdacyhalothrin. Susceptibility 


\section{PENDAHULUAN}

Malaria adalah penyakit menular yang disebabkan oleh protozoa genum Plasmodium, ditularkan ke manusia melalui gigitan nyamuk Anopheles betina yang berkembangbiak di sel darah merah manusia. ${ }^{1}$ Kabupaten Purworejo menjadi wilayah yang paling endemis malaria di Provinsi Jawa Tengah. Hasil survei entomologi yang dilakukan oleh Dinas Kesehatan Kabupaten Purworejo, spesies nyamuk yang ditemukan di Kabupaten Purworejo meliputi Anopheles aconitus, Anopheles maculatus, Anopeles balabacensis, Anopheles barbirostris, Anopheles vagus, Anopheles anularis, Anopheles kochi dan Anopheles minimus.

Spesies Anopheles yang ditemukan di Kabupaten Purworejo berbeda-beda berdasarkan tempat perkembangbiakan nyamuk tersebut. Terdapat beberapa tempat berkembangbiakan nyamuk Anopheles spp diantaranya area persawahan, perbukitan, hutan, pantai, dan aliran sungai. Dua per tiga wilayah di Kabupaten Purworejo merupakan wilayah dataran rendah dengan area persawahan yang luas sehingga mendukung tempat perkembangbiakan nyamuk Anopheles spp. ${ }^{2}$

Kepadatan Anopheles spp menjadi salah satu faktor penyebab terjadinya kejadian malaria di Kabupaten Purworejo. Meskipun sudah dilakukkan pengendalian vektor terhadap nyamuk Anopheles spp di Kabupaten Purworejo, akan tetapi masih ditemukan keberadaan breeding place Anopheles spp. Hal tersebut terjadi karena nyamuk Anopheles spp mampu mengembangkan sistem kekebalan tubuhnya terhadap paparan insektisida yang sering digunakan. ${ }^{3}$ Resistensi serangga terhadap insektisida umumnya setelah penggunaan 2-20 tahun. ${ }^{4}$ Sehingga, kejadian malaria di wilayah Kabupaten Purworejo masih tinggi. Kecamatan Pituruh adalah salah satu daerah dataran rendah yang selama empat tahun terakhir ini (2014 2017) tidak terdapat kasus malaria, padahal sebelumnya menjadi daerah yang KLB malaria diantara kecamatan lainnya yang termasuk wilayah dataran rendah. Hal tersebut didukung dengan kondisi topografi Kecamatan Pituruh yang terdiri dari area persawahan luas sebesar 2.486 ha, parit serta terdapat sungai yang mengalir, rawa dan area persawahan sebagai lingkungan yang berpotensi untuk tempat perindukan Anopheles spp. ${ }^{5}$

Pengendalian vektor malaria secara kimiawi telah dilakukkan, terutama pengendalian yang telah dilaksanakan oleh pemerintah diantaranya pemakaian kelambu berinsektisida dan Indoor Residual Spraying (IRS).6 Di Kabupaten Purworejo, jenis insektisida yang digunakan berbeda setiap tiga tahunnya. Hal tersebut dilakukkan untuk mencegah terjadinya resistensi nyamuk vektor malaria terhadap insektisida yang digunakan. Pada tahun 2014 - 2016 jenis insektisida yang digunakan adalah Lambdacyhalothrin Icon 100 CS, sedangkan sejak tahun 2017 jenis insektisida yang digunakan berupa Lambdacyhalothrin Icon $25 \mathrm{EC}{ }^{7}$

Penggunaan insektisida secara luas dan dalam waktu yang lama dapat menimbulkan resitensi terhadap nyamuk Anopheles spp.4 Saat ini, penggunaan insektisida jenis Pyrethroid menimbulkan kekhawatiran tentang masalah resistensi terhadap insketisida pada vektor malaria. Resistensi serangga terhadap insketisida muncul dipengaruhi oleh beberapa faktor diantaranya, formulasi insektisida yang digunakan, cara aplikasi insektisida, frekuensi penggunaan insektisida, serta lama penggunaan insektisida. ${ }^{8}$

Hal tersebut menjadi salah satu masalah dalam pengendalian vektor malaria. Oleh karena itu, diperlukan pemantauan tentang status resistensi masing-masing spesies vektor terhadap insektisida yang digunakan saat ini. ${ }^{9}$ Di Kabupaten Purworejo belum pernah dilakukan evaluasi kerentanan vektor malaria terhadap insektisida yang digunakan, sehingga perlu dilakukkan uji kerentanan nyamuk Anopheles spp terhadap insektisida Lambdacyhalothrin yang digunakan saat ini serta gambaran upaya pengendalian secara kimiawi yang dilakukkan oleh masyarakat terutama di Kecamatan Pituruh, Kabupaten Purworejo.

\section{MATERI DAN METODE}

Penilitian pada sampel nyamuk menggunakan rancangan ekperimen semu (Quasi Eksperimen), dimana terdapat dua kelompok yaitu kelompok perlakuan dan kelompok kontrol. Kelompok perlakuan mendapatkan paparan Lambdacyhalothrin

0,05\% sedangkan kelompok kontrol tidak diberi paparan. Populasi dalam penelitian ini yaitu nyamuk Anopheles spp betina keturunan F1, yang dipelihara dari larva di Kecamatan Pituruh. Sampel uji kerentanan adalah nyamuk Anopheles spp yang berjumlah 120 nyamuk dengan rincian pada masingmasing tube berisi 20 nyamuk dan pengulangan sebanyak 6 kali. Terdapat 6 tube dimana 4 tabung tube sebagai kelompok perlakuan dan 2 tabung tube kontrol

\section{HASIL DAN PEMBAHASAN}

\section{Knock Down Nyamuk Anopheles spp selama Pemaparan 60 Menit}

Pada menit ke 10, rata-rata nyamuk yang mengalami knock down pada tube perlakuan sebesar 8,75 ( 8 ekor), sedangkan pada menit ke 20 rata-rata nyamuk yang mengalami knock down sebanyak 12,75 (12 ekor). Menit ke 30, rata-rata nyamuk yang mengalami knock down sebesar 16,5 (16 ekor), menit ke 50 rata-rata yang mengalami knock down sebanyak 18,75 (18 ekor) dan pada menit ke 60 sebanyak 19,25 (19 ekor) yang mengalami knock down. 
Pada hasil pengamatan dilaboraturium yang telah dilakukan, maka pemaparan nyamuk Anopheles spp terhadap Lambdacyhalothrin $0.05 \%$ selama 60 menit sudah dapat memberikan gambaran terhadap hasil pemaparan setelah 24 jam. Hasil penelitian di Kenya Tengah, tidak ditemukan perbedaan jauh antara persentase akhir perlakuan 60 menit dan perlakuan 24 jam pasca holding. ${ }^{11}$ Hal tersebut relatif sama dengan penelitian ini, karena nyamuk yang mengalai knock down pada menit ke 60 lebih dari $90 \%$ dan dapat dikatakan bahwa sebagian besar nyamuk uji tidak dapat bertahan terhadap pengaruh Lambdacyhalothrin $0,05 \%$ selama pemaparan 60 menit.

Berdasarkan hasil pengamatan, rata rata jumlah nyamuk perlakuan yang mengalami knock down meningkat dengan semakin lamanya waktu pengamatan. Hal ini disebabkan karena Lambdacyhalothrin memiliki efek knock down yang cepat meskipum tidak stabil karena mudah mengalami degradasi. ${ }^{12}$

\section{Kematian Nyamuk Anopheles spp Pasca- Holding 24 jam}

Pada nyamuk uji dengan perlakuan, jumlah kematian nyamuk pada pengamatan 1 jam adalah 77 ekor (rata-rata 19,25 ekor) per pengulangan, pada pengamatan 2 jam dan 6 jam, jumlah nyamuk yang mati sebanyak 79 ekor (rata-rata 19,75) per pengulangan. Kematian nyamuk mencapai 80 ekor kematian nyamuk $(100 \%)$ pada pengamatan ke 12 jam. Berdasarkan perhitungan persentase mortalitas kematian nyamuk, diperoleh hasil sebesar $100 \%$ sehingga dapat dikatakan bahwa nyamuk Anopheles spp rentan terhadap Lambdacyhalothrin $0,05 \%$.

Penelitian yang dilakukan di Sulawesi Selatan, dimana seluruh nyamuk Anopheles barbirostris mengalami kematian (100\%) setelah kontak dengan Lambdacyhalothrin $0,05 \%$ yang berarti nyamuk Anopheles barbirostris rentan. Penelitian ini tidak sejalan dengan penelitian yang dilakukan di Sulawesi Tengah dimana Anopheles barbirostris resisten terhadap Lambdacyhalothrin $0.05 \%$ dengan persentase kematian nyamuk pasca holding 24 jam sebesar $73,4 \% .^{13}$

Pada dasarnya, proses terjadinya kerentanan serangga terhadap insektisida dipengaruhi oleh sejumlah faktor. Pertama adalah faktor genetik atau gen pembawa sifat rentan terhadap pestisida menjadi sumber pertama terjadinya proses kerentanan. Semakin banyak individu yang membawa gen rentan semakin cepat pula terjadinya kerentanan pada populasi tersebut. Kedua adalah faktor biologi yang meliputi jumlah generasi per tahun, mobilitas, jenis tanaman inang, parthenogenesis. Ketiga adalah faktor operasional yang terdiri dari jenis insektisida yang digunakan dan teknik aplikasi insektisida. ${ }^{8}$

Pengendalian vektor secara kimiawi terutama pengendalian dengan menggunakan insketisida, baik untuk nyamuk dewasa dan jentik akan merangsang munculnya seleksi pada nyamuk sasaran. Nyamuk atau jentik yang dapat terbunuh oleh insektisida akan mati, sedangkan yang resisten akan tetap hidup. Jumlah yang hidup lama kelamaan akan semakin banyak sehingga terjadi perkembangan kekebalan pada nyamuk atau jentik terhadap dosis tertentu insektisida. Proses terjadinya kekebalan menjadi penghambat utama dalam melakukkan pengendalian vektor menggunakan insektisida. ${ }^{9,13,14}$

Dari hasil uji yang telah dilakukan, artinya insektisida berbahan aktif lambdacyhalothrin $0,05 \%$ masih efektif digunakan dalam pengendalian vektor malaria terhadap nyamuk Anopheles spp yang telah dikonfirmasi sebagai vektor malaria di Kecamatan Pituruh dan Kabupaten Purworejo.

\section{SIMPULAN}

Nyamuk Anopheles spp yang di uji dinyatakan rentan terhadap Lambdacyhalothrin 0,05\%, dengan rata - rata knock down nyamuk Anopheles spp uji yang dikontakkan selama 60 menit terhadap Lambdacyhalothrin $0,05 \%$ sebesar 19,25 nyamuk $(96,25 \%)$ dan rata - rata kematian nyamuk Anopheles spp uji 24 jam setelah holding sebesar 20 nyamuk $(100 \%)$. Penelitian ini menujukkan bahwa nyamuk Anopheles spp rentan terhadap Lambdacyhalothrin, oleh karena itu Lambdacyhalothrin masih dapat digunakan untuk pengendalian vektor nyamuk Anopheles spp.

\section{DAFTAR PUSTAKA}

1. Marcus BA. Malaria (Deadly Diseases and Epidemics). Second. Marcus BA, editor. New York: Chealsea House Publishers; 2009. 11,12,23,22.

2. Bappeda Kabupaten Purworejo. Arsip Bappeda Kabupaten Purworejo. Purworejo; 2004.

3. Brogdon WG, Mcallister JC, Control D. Insecticide Resistance and Vector Control. In: Emerging Infectious Disease. Atlanta; 1998. p. 605-13.

4. Denholm I, Devine G. Insecticide Resistance. In: Perveen F, editor. Insecticides ( Advance in Integrated Pest Management) [Internet]. Croatia: InTech; 2001. p. 465-77. Available from:

https://pdfs.semanticscholar.org/8b25/41f4dda9 bb24fb2f90e795db8d9ae923b416.pdf

5. Ustiawan SF. Malaria di Desa Sokoagung, Kecamatan Bagelen, Kabupaten Purworejo: Karakteristik dan Faktor Risiko. BALABA [Internet]. 2015;11(01):51-8. Available from: https://media.neliti.com/media/publications/577 11-ID-malaria-in-sokoagung-village-bagelensub.pdf

6. World Health Organization. Malaria Vector Control Policy Recommendations and their Applicability to Product Evaluation [Internet]. 2017. 1-6 p. Available from: 
http://apps.who.int/iris/bitstream/handle/10665/ 255337/WHO-HTM-GMP-2017.12eng.pdf;jsessionid=D7B2CFDDE891C9C0C26 5989046F382FF? sequence $=1$

7. Dinas Kesehatan Kabupaten Purworejo. Profil Kesehatan Kabupaten Purworejo 2016. 2016.

8. Dani C. Manual Lengkap Malaria. Dani C, editor. Yogyakarta: Gosyen Publishing; 2014. 110-134 p.

9. Hunt RH, Fuseini G, Knowles S, Stiles-Ocran J, Verster R, Kaiser ML, et al. Insecticide Resistance in Malaria Vector Mosquitoes at Four Localities in Ghana, West Africa. Parasites and Vectors [Internet]. 2011;4(1):107. Available

from:http://www.parasitesandvectors.com/conte $\mathrm{nt} / 4 / 1 / 107$

10. World Health Organization. Test procedures for insecticide resistance monitoring in malaria vector mosquitoes. Second Edi. World Health Organization, editor. Geneva: World Health Organization 2016; 2016. 18-20 p.

11. Kamau L, Vulule JM. Status of insecticide susceptibility in Anopheles arabiensis from Mwea rice irrigation scheme, Central Kenya. Malar J. 2006;5:1-6.

12. Tristianti A, Hestiningsih R, Martini. Efektivitas Thermal Fogging Berbahan Aktif Sipermethrin 100 Gram/Liter Terhadap Kematian Nyamuk Aedes spp dan Penurunan Ovitrap. J Kesehat Masy. 2012;1(1):1-x.

13. Mustafa H, Jastal, Gunawan, Srikandi Y, Risti, Firdaus D. Peta Kerentanan Nyamuk Vektor Malaria Anopheles subpictus dan Anopheles barbirostris di Beberapa Daerah Endemis Malaria di Sulawesi Tengah. Balai Litbang P2B2 Donggala; 2012.

14. Widiarti, Boewono D, Barodji, Mujiyono. Uji Kerentanan Anopheles aconitus \& Anopheles maculatus terhadap Insektisida Sintetik Pyrethroid di Jawa Tengah dan DIY. J Ekol Kesehat [Internet]. 2005;4(2):227-32. Available from: http://ejournal.litbang.depkes.go.id/index.php/je $\mathrm{k} /$ article/view/1628 